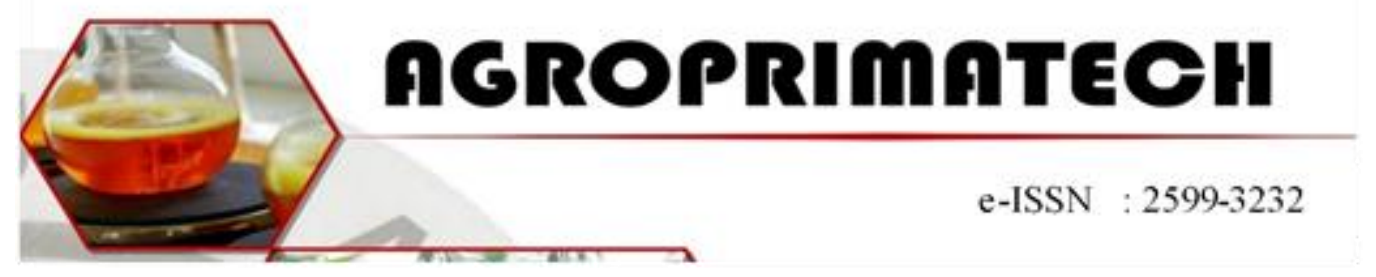

\title{
ANALISA KELAYAKAN KADAR N, P, K PUPUK ORGANIK CAIR SETELAH DIDEKOMPOSISI SELAMA 30 HARI
}

\author{
ULINA C. SIMATUPANG ${ }^{1}$ \\ ${ }^{1}$ Fakultas Pertanian Universitas Darma Agung \\ E-mail: jenni.ulina@gmail.com
}

\begin{abstract}
ABSTRAK
Penelitian ini bertujuan untuk membandingkan kelayakan kadar N, P dan $\mathrm{K}$ pupuk organik cair hasil dekomposisi anaerob dan aerob sampah organik berbahan baku air tahu, sayur dan buah dengan sampah organik berbahan baku air tahu dan ikan teri selama 30 hari. Hasil dekomposisi 30 hari sampah organik berbahan baku air tahu, sayuran dan buah menghasilkan pupuk organik cair dengan kadar $\mathrm{N} 0,15 \%$, P 0,08\% dan K 0,13\%. Hasil dekomposisi 30 hari sampah organik berbahan baku air tahu dan ikan teri menghasilkan pupuk organik cair dengan kadar $\mathrm{N} 0,30 \%, \mathrm{P} 0,18 \%$ dan $\mathrm{K} 0,10 \%$. Kadar $\mathrm{P}$ pupuk organik cair yang dihasilkan dari dekomposisi sampah organik berbahan baku air tahu dan ikan teri sudah memenuhi standart kelayakan SNI 19-7030-2004 yang ditetapkan kementrian pertanian sehingga layak digunaka pada tanaman. Kadar $\mathrm{N}$ dan $\mathrm{K}$ pupuk organik cair yang diperoleh dari dekomposisi sampah organik berbahan baku air tahu, sayur dan buah dengan sampah organik berbahan baku air tahu dan ikan teri belum memenuhi standar kelayakan SNI 19-7030-2004.
\end{abstract}

Kata Kunci: Sampah, Organik, Pupuk, Standar, Kelayakan

\section{PENDAHULUAN}

Menurut Taufik et al (2015) sampah pada umumnya dibagi menjadi dua jenis, yaitu;

a. Sampah organik

degradable (mudah diuraikan) mikroorganisme yang sebagian besar tersusun oleh senyawa organik (sisa tanaman, hewan atau kotoran) mengalami pembusukan atau pelapukan b. Sampah anorganik bersifat non degradable (sulit untuk diuraikan) mikroorganisme, sampah ini berupa plastik, botol dan logam.

Dari lapora Akhir Kajian Model Pengolahan Sampah dan SDM Kebersihan Di Kota Medan (2013) dijelaskan bahwa dengan populasi 3 juta jiwa, sampah yang dihasilkan setiap harinya mencapai 1.500 ton dengan perincian 48\% sampah organik dan $52 \%$ sisanya merupakan sampah anorganik. 
Pupuk organik adalah nama kolektif untuk semua jenis bahan organik asal tanaman dan hewan yang dapat dirombak menjadi hara tersedia bagi tanaman (Andesta et al, 2020). Menurut badan satndarisasi Nasional tahun 2002, "Organik" adalah istilah pelabelan yang menyatakan bahwa suatu produk telah diproses sesuai dengan standar produksi organik dan disertifikasi oleh otoritas atau lembaga resmi (Mayrowani, 2012). Berdasarkan Permentan

No.70/Permentan/SR.140/10/2011, pupuk organik merupakan pupuk yang berasal dari tumbuhan mati, kotoran hewan dan/atau bagian hewan dan/atau limbah organik lainnya yang telah melalui proses rekayasa, berbentuk padat atau cair, dapat juga diperkaya dengan bahan mineral, dan/atau mikroba yang bermanfaat untuk meningkatkan kandungan hara dan bahan organik tanah serta memperbaiki fisik, kimia dan biologi tanah (Hartatik et al, 2015).

Pupuk organik dapat berupa padat maupun cair yang terbuat dari bahan organik yang berasal dari hewan dan atau tanaman maupun dari limbah pertanian yang telah terdekomposisi dangan bantuan dekomposer (Pardiansyah et al, 2019). Pada dasarnya limbah cair dari bahan organik bisa dimanfaatkan menjadi pupuk, sama seperti limbah padatan organik yang banyak mengandung unsur hara (N,P,K) (Nur et al, 2016), selanjutnya dijelaskan proses pembuatan pupuk organik cair dapat dilakukkan pada keadaan anaerob dan aerob. Pengomposan aerob adalah dekomposisi bahan organik dengan kehadiran oksigen bebas (udara) dan pengomposan anaerobik adalah dekomposisi bahan organik tanpa mengunakan oksigen bebas.
Penelitian ini bertujuan untuk membandingkan kelayakan kadar $\mathrm{N}$, $\mathrm{P}$ dan $\mathrm{K}$ pupuk organik cair yang diperoleh dari hasil dekomposisi secara anaerob dan aerob sampah organik berbahan baku air tahu, sayur dan buah dengan sampah organik berbahan baku air tahu dan ikan teri. Diharapkan hasil penelitian ini dapat membantu masyarakat umum untuk dapat menghasilkan pupuk organik cair yang sesuai standart SNI secara mandir dan pelaku pertanian organik secara khusus serta menjadi bahan tinjauan bagi peneliti selanjutnya.

\section{METODE PENELITIAN}

Penelitian dilaksanakan dari bulan Januari 2013 sampai Juni 2013. Penelitian dilaksanakan dari bulan Juli 2020 sampai Agustus 2020. Kedua jenis bahan baku sampah organik didekomposisikan secara anaerob dan aerob terlebih dahulu selama 30 hari ( 1 bulan) setelah itu dilakukkan analisa kelayakan kadar hara $(\mathrm{N}, \mathrm{P}, \mathrm{K})$ dari pupuk organik cair yang diperoleh di Badan Penelitian dan Pengembangan Industri (Balai Riset dan Standarisasi Industri Medan) dengan metode Analisa SNI 19-7030-2004 (Trivana et al, 2017)

Alat dan bahan yang digunakan untuk membuat pupuk organik cair adalah sampah organik berbahan baku air tahu, sisa sayuran dan buahbuahan serta ikan teri yang diperoleh dari limbah rumah tangga dan limbah buangan penjual sayuran dan buah dari pusat penjualan sayuran dan buah di Perumnas Mandala Medan dengan berat masing-masing $3 \mathrm{~kg}$ (Nur et al, 2016), timbangan, ember besar yang akan digunakan sebagai tempat proese dekomposisi, dimana tutup atas dari ember tersebut diberi lubang, saringan, botol plastik dan 
selang yang berfungsi sebagai penghubung antara lingkungan luar dan lingkungan didalam ember.

\section{PROSEDUR PERCOBAAN}

Penelitian ini merupakan penelitian eksperimental.

\section{A. Pembuatan Pupuk Cair}

Sampah organik (sayur dan buah) berukuran besar dipotong dan dicacah terlebih dahulu kemudian dipilah berdasarkan katagori. Sampah organik berbahan baku air tahu, sayur dan buah dengan sampah organik berbahan baku air tahu dan ikan teri dimasukkan kedalam ember yang berbeda kemudian diberi label. Salah satu ujung dari pipa dipasangkan pada lubang tutup ember dan ujungnya yang lain dimasukkan kedalam botol yang berisi air bersih. Setelah pipa penghubung terpasang lalu ember ditutup rapat. (Siboro et al, 2013). Bahan organik yang ada di dalam ember dibiarkan mengalami proses dekomposisi secara anaerob dan aerob selama 30 hari (Trivana et al, 2017))

B. Analisa kadar N,P dan K

Analisa kelayakan kadar N, P dan $\mathrm{K}$ pupuk organik cair yang dihasilkan setelah dekomposisi sampah organik 30 hari menggunakan metode Analisa SNI 19-7030-2004, dilakukkan di/oleh Badan Penelitian dan Pengembangan Industri (Balai Riset dan Standarisasi Industri Medan)

\section{HASIL DAN PEMBAHASAN}

Hasil analisa kelayakan pupuk organik cair yang telah didekomposisi selama 30 hari dari sampah organik adalah sebagai berikut;

\section{TABEL 1}

SAMPAH ORGANIK

\begin{tabular}{|c|c|c|}
\hline \multicolumn{3}{|c|}{$\begin{array}{c}\text { (AIR TAHU, SAYURAN DAN } \\
\text { BUAH) }\end{array}$} \\
\hline $\begin{array}{l}\text { PARAMETE } \\
\text { R }\end{array}$ & $\begin{array}{l}\text { SATUA } \\
\mathbf{N}\end{array}$ & $\begin{array}{l}\text { HASI } \\
\text { L }\end{array}$ \\
\hline Nitrogen & $\%$ & 0,15 \\
\hline Fosfo & $\%$ & 0,08 \\
\hline Kalliu & $\%$ & 0,13 \\
\hline \multicolumn{3}{|c|}{$\begin{array}{c}\text { TABEL } 2 \\
\text { SAMPAH ORGANIK } \\
\text { (AIR TAHU DAN IKAN TERI) }\end{array}$} \\
\hline $\begin{array}{l}\text { PARAMETE } \\
\text { R }\end{array}$ & $\begin{array}{l}\text { SATUA } \\
\mathbf{N}\end{array}$ & $\begin{array}{l}\text { HASI } \\
\text { L }\end{array}$ \\
\hline Nitrogen & $\%$ & 0,30 \\
\hline Fosfo & $\%$ & 0,18 \\
\hline Kallium & $\%$ & 0,10 \\
\hline
\end{tabular}

\section{Kadar Nitrogen (N)}

Nitrogen (N) merupakan unsur makro yang diserap tanaman dalam bentuk ion nitrat atau amonium yang keduanya merupakan ion yang larut dalam air (Sonbai et al, 2013).

Pada tabel 1 pupuk organik cair dari dekomposisi sampah organik berbahan baku air tahu, sayuran dan buah diperoleh kadar Nitrogen $\quad 0,15 \%$. Berdasarkan standart uji sertivikasi kelayakan yang disahkan kementrian perindustrian kadar ini berada dibawah standart. Hasil ini sejalan dengan pernyataan peneliti sebelumnya yang menyatakan standart minimum $\mathrm{N}$ pada pupuk cair berdasarkan SNI 19-7030-2004 sebesar $0,40 \%$ (Yusmayanti et al, 2019)

Pada tabel 2 kadar pupuk organik cair dari dekomposisi sampah organik berbahan baku air tahu dan ikan teri diperoleh $\mathrm{N}$ sebesar 0,30\%, kadar ini hampir mendekati satandart kelayakan SNI 19-7030-2004 hal tersebut mungkinkan karena sampah organik yang digunakan mengandung bahan baku hewan (ikan teri), dimana menurut Simanungkalit et al (2006) ketersediaan unsur hara pada 
kotoran hewan lambat sehingga tidak mudah hilang.

Tidak tercapainya standart kelayakan minimum $\mathrm{N}$ pada tabel 1 dan tabel 2 sebagai pupuk organik cair untuk tanaman dikarenakan waktu dekomposisi yang lama (30 hari), sebab menurut Meriatna et al (2018) setelah waktu 16 hari kadar $N$ mulai menurun dan penurunan kadar $\mathrm{N}$ juga disebabkan oleh karena $\mathrm{N}$ bereaksi dengan air membentuk $\mathrm{NO}_{3}$ - dan $\mathrm{H}^{+}$(Trivana et al, 2017)

\section{Kadar Fospor (P)}

Dari tabel hasil pengamatan pupuk organik cair, tabel 1 yang merupakan hasil dekomposisi secara anaerob dan aerob sampah organik berbahan baku air tahu, sayur dan buah menghasilan kadar P 0,08\% sedangkan tabel 2 hasil dari dekomposisi secara anaerob dan aerob sampah organik berbahan baku air tahu dan ikan teri menghasilkan kadar P 0,18\%. Selisih kadar $\mathrm{P}$ yang dihasilkan tidak jauh berbeda tetapi dari data tersebut juga menunjukkan bahwa kadar pupuk organik cair dari dekomposisi sampah organik berbahab baku air tahu dan ikan menghasilkan kadar fospor (P) lebih banyak sehingga memenuhi standart minimum kelayakan SNI 19-7030-2004 serta layak untuk diberikan pada tanaman

Tingginya kadar $P$ pada tabel 2 dikarenakan bahan baku sampah organik yang didekomposisikan selain air tahu juga berbahan baku ikan teri (hewan) yang berasal dari laut dan mengandung mineral tinggi, seperti yang dinyatakan Sari et al (2017), ketersediaan P dapat secara langsung melalui proses mineralisasi bahan organik dan Kuswinarni et al (2020) sisa-sisa makanan dan tepung tulang (hewan) dapat meningkatkan kadar fospor $(P)$.
Pengamatan lebih lanjut dengan membandingkan hasil kadar $P$ pupuk organik cair dari tabel 1 dan tabel 2 menunjukkan bahwa peningkatan kadar fosfpor $(\mathrm{P})$ pada tabel 2 selaras dengan peningkatan kadar nitrogen (N). Menurut (Trivana et al, 2017) peningkatan kadar $\mathrm{P}$ juga dipengaruhi oleh tingginya kadar $\mathrm{N}$ dan semakain besar kandungan $\mathrm{N}$ maka multiplikasi mikroorganisme yang merombak $P$ akan meningkat sehingga kandungan $P$ dalam pupuk cair juga meningkat (Hidayat et al 2011).

\section{KADAR KALIUM (K)}

Hasil analisa pupuk organik cair tabel 1 menunjukkan bahwa kadar Kalium (K) yang diperoleh hampir mendekati standart kelayakan SNI 19-7030-2004, namun belum mencapai presentase yang diharapkan hal tersebut terjadi dikarenakan unsur $\mathrm{K}$ itu sendiri dimanfatkan oleh mikroba dalam proses dekomposisi (Nur et al, 2016) juga dikarenakan pengaruh masuknya udara kedalam ember dekomposisi (fermentasi) (Mariatna et al, 2018)

Lebih tingginya kadar kallium pada tabel 1 dikarenakan bahan baku pembuatan pupuk organik banyak menggunakan sayuran hujau, seperti pernyataan peneliti sebelumnya bahwa kallium pada kompos berasal dari materi dasar kompos yang berupa sayuran hijau yang didalamnya sudah terdapat unsur kallium (K) (Kuswinarni et al, 2020),

Tabel 1 Pupuk organik cair yang diperoleh dari hasil dekomposisi sampah organik berbahan baku air tahu, sayuran dan buah diperoleh kadar kalium 0,13\% hasil ini sedikit lebih tinggi jumlahnya dibandingkan dari tabel 2 (sampah organik berbahan baku air tahu dan ikan teri) yang menghasilkan kadar kallium 
$0,10 \%$. Tidak tercapainya standart kelayakan minimum pupuk organik yang telah ditetapkan kementrian pertanian disebabkan pada proses dekomposisi kedua jenis bahan baku sampah organik tersebut tidak menggunakan campuran air urine hewan, seperti yang dinyatakan oleh peneliti sebelumnya bahwa untuk menaikan kadar unsur hara pupuk organik cair maka digunakan bahan aditif yaitu urine kambing (Nurjannah et al, 2018) dan tidak adanya perlakuan pengadukan, seperti yang dinyatakan Cagayana et al (2018) kompos dengan frekwensi pengadukan lebih tinggi akan menghasilkan kadar kallium yang tinggi.

\section{KESIMPULAN}

Hasil analisa perbandingan pupuk organik cair dari dekomposisi sampah organik berbahan baku air tahu, sayuran dan buah serta sampah organik berbahan baku air tahu dan ikan teri diperoleh hasil sebagai berikut;

1. Pupuk organik cair dari dekomposisi sampah organik berbahan baku air tahu dan ikan teri sudah menghasilkan kadar fospor (P) sesuai standart kelayakan SNI 19-7030-2004 yang ditetapkan kementrian pertanian.

2. Setelah dekomposisi 30 hari, sampah organik berbahan baku air tahu, sayuran dan buah serta sampah organik berbahan baku air tahu dan ikan teri keduanya belum menghasilkan kadar unsur hara $\mathrm{N}$ dan $\mathrm{K}$ sesuai standart SNI 19-7030-2004

3. Pemilihan jenis bahan baku sampah organik dan lamanya Waktu (hari) dekomposisi harus diperhatikan untuk memperoleh pupuk cair organik yang sesui standart SNI 19-7030-2004

\section{DAFTAR PUSTAKA}

Andesta, D., Rahim, A.R., Sukaris., Fuziyah, N., Risma, I.D., Chandi, N., Ermawati, S. 2020. Pemanfaatan Limbah Sampah Rumah Tangga Menjadi Pupuk Organik Di Desa Banjarmadu. DedikasiMu (Journal of Community Service). Vol 2, No 2.

Cagayana., Samudro, G., Hadiwidodo, M. 2018. Penentuan Pengadukan Optimum Berdasarkan Pengomposan Dan Produksi Listrik Dalam CSMFCs (Compost Solid Phase Microbial Fuel Cells). Jurnal Sains dan Teknologi Lingkungan. Vol 10, No 2. 88100

Hartatik, H., Husnain., Widowati, L.R 2015. Peranan Pupuk Organik Dalam Pningkatan Produktivitas Tanah dan Tanaman. Balai Penelitian Tanah. Jurnal Sumber Daya Lahan. Vol 9. No. 2, Desember 2015. 107-120.

Hidayat, Y. A., Kurnani, T. B., Marlina, E. T., Harlia, E. Kualitas Pupuk Cair Hasil Pengolahan Fese Sapi Potong Menggunakan Saccharomyces cereviceae (Liqiud Fertilizer Quality Produced by Beef Cattle Feces Fermentation Using Saccharomyces cereviceae). Jurnal IImu Ternak. Vol. 11, No. 2. 104-107.

Kaswinarni, F., Nugraha, A. A. S. 2020. Kadar Fosfor, Kalium dan Sifat Fisik Pupuk Kompos Sampah Organik Pasar 
Dengan Penambahan Starter EM4, Kotoran Sapi Dan Kotoran Ayam. Jurnal IImiahMulti Sciences. Vol 12, No 1. 1-6.

Meriatna., Suryati., Fahri, A. 2018. Pengaruh Waktu Fermentasi dan Volume Bio Aktivator EM4 (Effective Microorganisme) Pada Pembuatan Pupuk Organik Cair (POC) dari limbah BuahBuahan. Jurnal Teknologi Kimia Unimal.

Mayrowani, H. 2012. Pengembangan Pertanian Organik Di Indonesia (The Development of Organic Agriculture in Indonesia). Forum Peneliti Agro Ekonomi. Vol 30, No 2. 91-108

Nur, T., Noor, A.R., Elma, M. 2016. Pembuatan Pupuk Organik Cair Dari Sampah Organik Rumah Tangga Dengan Penambahan Bioaktivator $\mathrm{EM}_{4} \quad$ (Effective Microorganisme). Konversi. Vol 5, No 2.

Nurjannah, N., Arfah, N., Fitriani, N. 2018. Pembuatan Pupuk Organik Cair Dari Limbah Biogas. Journal Of Chemical Proses Engineering. Vol 03, No 01.

Pardiansyah, D., Ahmad, N., Firman., Martudi, S. Pupuk Organik Cair Dari Air Limbag Lele Sistem Bioflok Hasil Fermentasi Aerob dan Anaerob. Jurnal Egroqua. Vol 17, No 1

Pemerintah Kota medan. 2013. Laporan Akhir Kajian Model
Pengelolaan Sampah Dan SDM Kebersihan Di Kota Medan.

Sari, M. N., Sudarsono., Dermawan. 2017. Pengaruh Bahan Organik Terhadap Ketersediaan Fosfor Pada Tanah-Tanah Kaya Al dan Fe. Buletin Tanah dan Lahan, 1(1). 65-71.

Siboro, S.T., Surya, E., Herlina, N. 2013. Pembuatan Pupuk Cair Dan Biogas Dari Campuran Limbah Sayur. Jurnal Teknik Kimia USU. Vol 2, No 3.

Simanungkalit, R.D.M., Suriadikarta, D. A., Saraswatu, R., Setyorini, D., Hartatik, W. 2016. Pupuk Organik Dan Pupuk Hayati (Organic Fertilizer And Biofertilizer). Balai Besar Litbang Sumberdaya Lahan Pertanian. Badan Peneliti Dan Pengembangan Pertanian.

Sonbai, J.H.H., Prajitno, D., Syukur, A. 2013. Pertumbuhan Dan Hasil Jagung Pada Berbagai Pemberian Pupuk Nitrogen Di Lahan Kering Regosol. IImu Pertanian. Vol 16, No 1.77-89

Trivana, L., Yudha, A., Pradhana, Y. 2017. Optimalisasi Waktu Pengomposan dan Kualitas Pupuk Kandang dari Kotoran kambing dan debu Sabut kelapa Dengan Bioaktivator PROMI dan Orgadec. Jurnal SAIN VETERINER. Vol 35, No.1

Tufik, A., Maulana, M. F. 2015. Sosialisasi Sampah Organik Dan Non Organik Serta Pelatihan Kreasi Sampah. 
Agroprimatech

Vol. 4 No. 2, April 2021

Jurnal Inovasi dan

Kewirausahaan. Seri

Pengabdi Masyarakat. Vol 4, No 1.68-73

Yusmayanti, M., Asmara, A.P. Analisa Kadar Nitrogen Pada Pupuk Urea, Pupuk Cair dan Pupuk Kompos Dengan Metode Kjeldahl. 